DOI: $10.15503 /$ jecs20142.144.153

\title{
SOCIAL BARRIERS TO EFFECTIVE COMMUNICATION IN OLD AGE
}

\author{
ANNA SANECKA \\ The Christian Theological Academy in Warsaw, Faculty of Theology, \\ Miodowa 21C, 00-246 Warsaw, Poland \\ E-mail address: asanecka@gazeta.pl
}

\begin{abstract}
Some communication barriers apply particularly to elderly people. The social barriers to effective communication in old age are the barriers caused by stereotypes of old age/elderly people and the barriers arising from limitations in using mass communication by seniors. Stereotypes of old age/elderly people embrace views regarding old people's communication skills and the ideas about the correct way of communication with them. Therefore the communication problems of old people are correlated with the little and poor communication processes they are participating in. This seems to be a result of impetuses of poor quality sent to seniors by their communication partners. Not only face to face communication but also mass communication is very important for the elderly population. Therefore limitations in using new technologies and new communication channels as well as a limited presence in the mass media of content created by seniors and for seniors have an impact on their life, their well-being, and their interpersonal relationships. These problems are especially important when we faced with the ever growing population of elderly people.
\end{abstract}

Keywords: old age; communication; communication barriers; social barriers; stereotypes; mass communication; uses of mass communication; elderly/old people; stereotypes of elderly people/old age; ageism

\section{INTRODUCTION}

Old age is difficult to define and its borders are difficult to identify. The easiest way to pinpoint its beginning is to employ biological criteria and check in the World Health Organization website ${ }^{1}$. On the WHO's site we do not find its definition nor the information where old age starts, but we will be equipped with some useful data. We get the following information (1) Most developed countries have accepted the chronological age of 65 years as a definition of "elderly" or older person as being the age one can begin to receive pension benefits; (2) At the moment there is no United Nations standard numerical criterion, but the UN agreed it is 60+ years to refer to the older population; (3) As far back as 1875 in Britain the Friendly Societies Act enacted the definition of old age as "any age after 50"; (4) If a definition in Africa is to be developed, it should be either 50 or 55 years of age (World Health Organization, 2014). In this paper we will understand old age following Jerzy Piotrowski's definition: old age is "a cultural phe-

Although an old age is not a disease, it is a condition. Therefore it is in WHO's area of interests. 
nomenon developed on biological bases and connected with losing energy" (1973, as cited in Szarota, 2004, p. 22).

Not only "old age" but also "communication" is not easily defined. A number of different definitions of communication are presented by Barbara Sobkowiak (1998) - we will understand communication as a "process of creating, processing and exchanging information between people, groups and social organizations. The aim of communication is to continuously and dynamically create, modify or change knowledge, attitudes and behaviour in the direction consistent with values and interests of the parts of interaction" (p. 11).

Communication is one of the basic social processes. It allows people, groups and organisations to create, process, send and receive information about facts, thoughts and emotions. Communication is the condition of effective acting and fulfilling needs. It makes cooperation, self presentation and keeping in touch possible and it influences one's behaviour. Communication as a field of academic knowledge is still developing and the number of publications on this subject is growing. Interestingly, it seems that in Poland papers about communication in any particular period of human life usually focus on the stage of early childhood and adolescence. The period when one just learns to talk and communicate as well as the process of developing these abilities is widely described in psychological and pedagogical literature. It seems less interesting for scientists to study adult people's communication. The exception is communication in organizations and marriages.

Communication is not always effective. Different communication barriers are widely known and described, starting from physical ones such as noise or lack of time for communication, going through emotional and language barriers, ending by lack of trust toward the message sender, information overload and inability to listen. Barriers are located on senders' or recipients' sides or in the message itself. In some sense they are related to people in the interaction and not referring to their sex, age, education or IQ. The barriers to effective communication are, therefore, everything that disturbs or precludes effective communication. The "social barriers" are prejudices and stereotypes effecting the communication process and social thinking about communication (with old people). On the other hand, there is the availability and use of mass media such as television, radio and the Internet.

\section{FACE-TO-FACE COMMUNICATION WITH ELDERLY PEOPLE}

Some of the barriers particularly apply to elderly people. Communication skills of old people depend on their individual characteristics, but can also be described as an attribute of the entire group and related to its age. From this point of view Zając (2002) characterised the psychological changes and disorders of elderly people ${ }^{2}$. Some of the barriers are purely biological and are caused by weakening of hearing and seeing as well as by changes in the central nervous system. While one gets older, the functions of the brain are declining and some structural and chemical changes are developing. The

2 Note: "their common qualities are strictly related to specific situation of being old, but individual qualities have their origins in personality" (Zając, 2002, p. 57). 
number of neurones is decreasing, the bodies and dendrites of the nerve cells are getting smaller and their internal structures are changing. The number and size of fibrous astrocytes are growing. These changes effect the intellectual abilities. The capacity for short term memory decreases as well as the ability to recall and identify. Coding of new information begins to be more simple and it results in using more stereotypes. Selectivity and concentration become weaker, fatigue is much quicker and mistakes more common. There are some more difficulties in processing received information. For about 10$20 \%$ there is an increase in reaction time ${ }^{3}$. Getting old is connected with losses in some kinds of intelligence as well as with troubles of generalizing and abstracting. Intelligence is usually divided into two kinds: fluid and crystallized. Crystallized intelligence is the skills and abilities developed during education and one's own experiences. Verbal skills, understanding, vocabulary are parts of crystallized intelligence and they are persistent till the age of 70 . Fluid intelligence refers to non-verbal skills such as abstract reasoning or reaction time. Because many meanings in communication are connected with non-verbal messages, the problems with receiving them caused by deficits of fluid intelligence are easily spotted and make the communication process more difficult. If we add to this picture problems with function of the senses like dysfunction of seeing (which includes about $40 \%$ of old people ${ }^{4}$ ) and hearing (about $30 \%$ of people $65+$ can identify their own problems with hearing $\left.{ }^{5}\right)$, we will understand that there is a wide range of communication barriers and problems particularly applying to old people.

A very important problem is related to specific old age diseases (like Alzheimer's disease, vascular dementia or aphasia as a result of brain damage or stroke) and their results. This chronic disease results in attempting to understand both the world and life. Social barriers to effective communication of an ill person should be studied in separate research beyond the study of old people's communication.

Besides all the biological changes resulting in communication barriers there are many social obstacles to old people's communication. These are most of all the stereotypes of old age and elderly people. This is also the stereotypical thinking of old age impacting the communication ability as well as expected ways to communicate with elderly people. These barriers are located on the senders' side. The senders either do not consider specific disabilities of old people or, on the contrary, they do credit old people with some limitation according to social practice. While they are not old themselves, they do not know nor understand the problems of old age, although "it is enough to put some cotton wool into your ears, some stones into your shoes, rubber gloves onto your hands and apply petroleum jelly on your glasses and we get readymade old age" (Viorst, 1996, p. 323) .

3 Reaction time is the amount of time needed by an individual to react to stimuli. It is very important for keeping and regulating conversations. For elderly people it is important to be very strict. They care more for accuracy then for speed. Increase of reaction time is widely recognised as a decline of cognitive abilities than increasing care.

4 Seeing is very important for communication. Many non-verbal messages are visual and even slight deficit in seeing acuity results in communication abilities. Drop in ability of visual impulse processing obstructs communication.

$5 \quad$ Worsening of hearing means a drop in sensitivity to high frequency sounds and weakening ability to differentiate adjoining sounds. That is the reason why speaking seems to be unclear and the words intermingle even if they are pronounced loud enough to be heard. These problems increase when speaking is quick or accompanied by external noises as well as in stressful, high pressure situations. Statistical data derived from research presented by Bień (2002, p. 42). 
American research conducted by Howard Giles, Susan Fox and Elise Smith (as cited in Nussbaum, Coupland, 1995, p. 105) shows that both middle-aged and young people as well as the older population share many stereotypes concerning old people. These are both positive and negative stereotypes but they are always connected with the communication aspect of behaviour. Following Adam Schaff's definition, stereotype in this paper will be understood as "evaluative judging (negative or positive) connected with belief, which has the following qualities: 1 . its subjects are most of all some groups of people and social relations between them, 2. its genesis is social and it is not connected with individual experiences but it is transferred by family and society as a social opinion during socialization, 3 . it always has some emotional (positive or negative) charge, 4 . it is either completely contradictory to facts or simulating to be truthful while it is only partly consensual with facts, 5 . it is long lasting and resistant to changes, which is connected with its emotional charge and independence from one's experiences, 6 . the characteristics mentioned above let the stereotype realize its social function which is to defend socially accepted values or judgments. The internalization of such values or judgments as valid social rules is the condition of integration with the group (1993, p. 23).

Leszek Kołakowski wrote that stereotypes are "natural and beneficial brain functions; stereotypes - of things, people, nations, places - are different, some can be defensive, some are half-true, some completely false, but because they are indispensable for our mental safety, they can usually triumphantly last in defiance of opposite experiences unless they result in any very harmful effects" (2004, p. 199).

Therefore we should think about harmful effects of stereotypical thinking about old people as colourless figures slowly walking through long corridors of residential homes, sitting in waiting rooms of clinics or spending their time in cemeteries or churches. We should reassess the thinking that these are the pictures and places typical for elderly people. In Polish we do not have an equivalent to the English "ageism" - the word similar to racism or sexism. This word describes the discrimination on the undertow of age. The way of thinking mentioned above is just the result of the negative, stereotypical perception of old age. Głogowska (2005) shows the way some older Polish intellectuals are treated just because of their age. The author emphasized the meaning of words "yet", "last" or "never" which receive new and specific senses for the people 65+.

But we should also focus on some specific words which are used to describe old age, old people's activity or their abilities. These words especially emphasize the association between old age and a decrease of abilities, intelligence, and life force. Therefore, we say that what an old person "can do is not bad for his/her age", he/she "still can" and that his/her achievements or abilities are "incredible" or "unique". That is why we ask old people in good shape what helps them keep fit and relatively young. All these expressions strengthen social beliefs about things old people do or should do. They emphasize the general belief that what we see is some kind of a phenomenon, something unusual. That it will not last long and that the norm of activity, health condition or achievements for old people in general are quite different from what we see in this particular case (Głogowska, 2005).

Studies held for many years by American researchers on associations between stereotypes of old age/old people and communication which are widely described in Handbook of communication and aging research (Hummert, Shaner, \& Garstka, 1995, p. 105-132) show that stereotypes are one of the main factors impacting communication with elderly people.

Younger people extravagantly tailor their conversational ways to the stereotypical perception of old people's physical and intellectual limitations. Regarding research re- 
sults (Hummert, Shaner, \& Garstka, 1995, pp. 656-670) social understanding of old age is multidimensional. Stereotypes arising from these complex ideas are either positive or negative in their emotional charge. Older adults have more complex stereotype syndromes than young or middle aged people. The social genesis of stereotypes and their independence from life experiences notwithstanding, some syndromes of stereotypes of old age differ regarding personal experiences with old people. The consequence of different stereotypes of elderly people is a difference in attitudes towards old people - positive towards some of them and negative towards others. The attitudes differ regarding a particular old person and his/her attributes as well as the particular circumstances or relationship. However, the attitude towards old people is - in general - more negative than towards younger persons.

Beliefs concerning communication with old people can include views regarding their communication skills or ideas regarding proper style of communication with old people. An average 75-year-old person is seen as somebody who experiences more problems when receiving information or communicating than an average 25-year-old. The problems with receiving information relate to understanding the conversation partner in a situation of noise or losing a strand. Problems with communication involve lessening the frequency of using difficult words or difficulties in talking under the pressure of time. Old people are found to be more competent conversation partners than younger ones only in two points: (1) honesty in conversation and (2) narrative skills.

It seems interesting that different stereotypes of old people lead to different beliefs about their communication skills. The people representing positive stereotypes (still active, healthy, etc.) are judged as ones with better communication skills and less communication barriers than the ones of the same age but representing negative stereotypes (ill, lonely, etc.). Positive or negative judgment about old age and old people leads to different behaviour - also communication - towards old people as well as to defending existing stereotypes about old people. Negative stereotypes more often concern people over 80 with big health problems and in the negative context of old age such as nursing homes. Positive stereotypes are related with people in their $60^{\prime}$ s or $70^{\prime}$ s in good health and showing positive facets of old age.

Attitudes towards old people and their communication skills can suggest some strategies which conversation partners will use when talking with seniors. If an interlocutor believes that an elderly person has some hearing problem, some problem with remembering the words or processing the language, then he/she can use some patronising way of talking or even a specific - reserved for children - way of talking called "baby talk". It usually means he/she will talk loudly, slowly and using simple sentences. If the conversation partner talks to an old person like this he/she can provoke a senior's behaviour in such a way that will prove/fulfil? his/her negative stereotypes of old age and old people. Not only the way of talking but the communication itself can be distorted because of stereotypes. It can be simplified because it is compatible with widespread stereotypes of old people's intellectual skills as well as their cognitive abilities.

Thinking in economic terms, people surrounding seniors send them impetuses of poor quality. It is the action based on some social stereotypes that old people cannot receive some of the impetuses because of a deterioration of hearing or seeing and some cannot process information because of age related changes in their brains. Young and old people often do not understand each other because of their very different past experiences, social and economic situations, life stages and many other factors that make sharing and co-creating meanings very complicated. Young people tend to act 
unnaturally friendly in conversation with seniors. This unnatural way of interaction can have disastrous influence on relationship development. It can create and promote stereotypical attitudes which make cross generation communication problems even greater. Catch 22 situations develop when younger communication partners modify their way of talking in conversation with an elderly person. Seeing seniors as people of lessened communication abilities (because of hearing disorders), they make their statements simpler. In a conversation with a partner whose communication skills are judged as poor, people tend to use simpler and more definitive? words, to create simpler and shorter sentences, to speak more slowly and intensify non-verbal information. Therefore, a senior can sense that his/her proficiency to communicate is missing. Their belief about their own ability to see or hear is ruined. This leads directly to a decrease in self-confidence and avoidance of future conversation. Seniors themselves acquiesce to the stereotypical thinking about their communication competencies. In such a situation interlocutors are getting the proof of seniors' communication incompetence, and both sides step back from the conversation. Both are unsatisfied and less willing to be involved in such conversations in the future.

The assumptions made while getting into or avoiding conversations with elderly people are based on social perception of old age and old people. They are connected with stereotypes of old age and lack of abilities of elderly people. They are also connected with prejudice based on these stereotypes.

Communication, just like most abilities, requires practice. Our communication skills are much less dependent on our age or sex than they are on the number of communication interactions we are involved in. The communication problems of old people are correlated with little and poor communication processes they are participating in. Seldom, unsatisfying and difficult communication acts of elderly people may therefore be the cause, not the result, of deepening communication problems.

\section{ELDERLY PEOPLE AND MASS COMMUNICATION}

The next group of social barriers in seniors' communication - besides the ones based on stereotypical perception of old age, its limitations and their influence on communication - is the way of using mass communication. Mass communication is the communication through mass media. Limitations in using mass communication will apply to receiving mass messages, on the one hand, and broadcasting one's own messages using mass media, on the other. The first category of barriers in this group is connected with accessibility to the Internet for elderly people and using it for communication. The media such as TV, radio or newspapers are widely available for everyone, and this accessibility is not connected with age. But new technologies and new communication channels for many reasons are limited to the middle-aged, young and very young people. In Poland, unlike in the US or Canada, there are not many internet sites about old people and for old people concerning special needs, interests or barriers for seniors. In the US the number of media caring about old people is growing rapidly, and the subjects they raise are not only social services or old age illnesses but also involve the life and achievements of elderly people.

The second category of barriers is the limited presence of content created by seniors in the mass media, i.e. content presenting their ideas and beliefs as well as raising interesting subjects for seniors and from their point of view. There are magazines addressed 
to women, children, young parents, cat or garden lovers. There are TV programs for overweight people, youngsters or Christians. But there are almost no programs or papers addressed to seniors. On the Internet only few titles of TV programs for elderly people can be found (TV Seniors Club, Being a senior, Jolanta Kwaśniewska's program in Question for breakfast is no longer broadcast). The number of titles of magazines or newspapers is not much bigger. On the internet site Ask Polska we can find 7-8 titles.

The Google search engine adds three more titles to the list. Red Wallet Senior (www. czerwonyportfelik.pl/cp-senior) in the article What peeps in the grass: subjective review of magazines for people 50+ (Co piszczy w prasie dla Seniorów: subiektywny przeglad magazynów dla osób 50+) presents four more titles from the British market.

The way of using the media is particularly important as it impacts interpersonal relationships and can impact the way of perceiving aging and old people. Referring to American research presented in the chapter Mass Media Use and Aging in Communication and Aging (Nussbaum, Pecchioni, Robinson, \& Thompson, 2000), we can notice that mass media are very important for the older population. Old people spend about $40 \%$ of their time using mass media. Media allow them to keep in touch with the changing world. Media provide them with some subjects for conversations. Sometimes media substitute for real interpersonal relations.

The amount of time used for TV watching increases as people get older. Old people watch more television than any other age group including children. Old Americans prefer to watch news broadcasts like news services, documentary or journalistic programs as well as travel programs and game shows. Old people like television programs showing the people of their own or of similar age. As opposed to time spent on television watching, the amount of time devoted to radio listening decreases along with aging. Adults listen to the radio for news, weather forecasts, warnings about risks as well as for music. Old people choose the stations with news, journalistic programs and radio talkshows.

The amount of time devoted to reading also decreases while one is getting older. It refers both to books and magazines as well as everyday newspapers, although old people read less books than magazines or newspapers. Although reading in general is decreasing, reading of newspapers is increasing during life till the age of 70 . The falling of newspaper reading in this age is connected to senile problems with eyesight. Old people like to read news, journalistic texts, political articles, letters to the editor as well as texts about social services and health.

Old age in Poland is very different from old age in the United States. Besides the much better material and health situation of American seniors, the differences concern the use of media communication, especially such interactive ones as Internet or PCs. In the US a special non-profit organisation - SeniorNet - was created to help old people get to know new technologies. The members of SeniorNet are people 50+ who help other elderly people use computer technology. They teach each other how to edit texts, use the Internet or e-mails, and manage home budgets using computer programs. SeniorNet also leads two discussion groups which embrace a wide range of subjects. As the results of a phone survey carried out in November 1995 on people over 55 years ${ }^{6}$, many elderly people have learned to use new technology and the number of computer enthusiasts is still growing. Most old people use the computer for text editing (80\%), playing (60\%), financial managing $(54 \%)$, typesetting (34\%), on-line navigating services $(28 \%)$. One of the main reasons elderly people use computers is e-mailing. The possibil-

$6 \quad$ The survey ordered by Intel Corporation. 
ity to keep in touch with children and grandchildren living in other parts of the country is treated as one of the greatest conveniences offered by computers. It seem that old people use PCs mostly to cultivate social relationships.

Communication via the computer lets elderly people avoid some of the barriers they meet in face to face communication. They can communicate with much younger people and build satisfying relationships which are not marred by stereotypes of old people and aging. By their own good experiences with old computer users, younger people can be less prone to negative attitudes towards old age and old people.

Besides all the differences between Poland and the US it seems that the interest in using computers, the internet and e-mails among old Poles is similar to that across the ocean. As Bugajska writes in her article Jak dziadkowie buszuja w sieci (How the old folks poke around the Web): "Polish seniors envied their grandchildren because of the internet. So they diligently learned how to click the mouse, send e-mails and create accounts" (Bugajska, 2005). But despite great interest in computer courses among old people, not many institutions decide to organise them. Those who come up with such a challenge cannot complain - they have plenty of people interested in such courses. But others still stereotypically think about old people and believe they are more interested in excursions to Lichen $^{7}$ or Jasna Góra ${ }^{8}$ than in the Internet. Statistical data which the author quotes prove that the percentage of seniors using the Internet is rather low in Poland. In this field not only the United States or Germany but also Estonia left us behind. "In Poland only 3.6 \% of people over 60 use the Internet (data according to TNS OBOP), while in Germany it is $25 \%$. Somebody may say: »Our seniors are poor «. But in Estonia (where average pension is about 625 PLN) the Internet is used every day by $19 \%$ of old people. And it is the result of sensible state politics. In Germany under the auspice of federal government this spring in 222 localities the program 50plus ans Netz (Getting people over 50 into the Net) was started. In Estonia there are 60 free of charge centres where seniors can learn computer skills. Television channel TV3 is also handling an Internet course" (Bugajska, 2005).

Looking through American research concerning computer use among old people and considering the interest of seldom offered computer courses among Polish seniors, we have to believe that a joke about special computers for old people published on the web is not only tasteless, but also untrue ${ }^{9}$. Their creators must have submitted to stereotypical thinking about old age and old people.

7 A location of Marian Shrine - one of the most special places among the Marian Shrines worldwide (see: http://www.lichen.pl/pl/378/jezyki_obce; retrieved: 01.07.2014)

8 A location of Sanctuary of Black Madonna of Częstochowa; the complex is one of the most important sites of Marian worship and the heart of pilgrimage in Poland; see: http://www.jasnagora.pl/en, retrieved: 01.07.2014)

9 Note: "Some computer manufacturer wants to launch this year the computer intended for old people. This seniors' PC has undermentioned characteristics: (1) the home page is Word form - Will.doc; (2) the monitor is 42 inches in different options from -6 to +6 dioptre; (3) in the already installed popular game

"duck shooting" the player can also feed the birds; (4) the game Minesweeper is available in two versions "Stalingrad" or "Normandy"; (5) the loudspeakers are factory-made for the higher sound level; (6) for all the components the manufacturer gives life time guarantee; (7) internet home page is different according to the country and it is either www.radiomaryja.pl or www. oma-sex.de; (8) the mouse has built-in stabilizer which buffers the nuisance of Parkinson Disease; (9) if for 15 minutes there is no activity on turned on computer, the ambulance is called automatically; (10) hire purchase is unavailable". Retrieved April 23, 2014 from http:/ / www.teksty.jeja.pl/162,pecet-dla-seniorow.html. 


\section{CONCLUSION}

Communication is the base of satisfying interpersonal relationships. People's ability to create and cultivate interpersonal relations influences their psychological and physical health, time needed for recovery in any case of illness and even the length of life. Besides the physical disorders such as feeling of tiredness, headaches, insomnia, increased peevishness, joints and spine aches, disorders of digestive and urinary systems, the social barriers to communication are regarded as the main reasons for the social seclusion of elderly people. This problem seems especially relevant because psychological and physical ailments make an old person especially dependent on help from other people - family members, doctors, neighbours, social workers. As Z. Szarota described it: "in no other period of life the human fate depends so much on his/her personality, character, habits and competence to cooperate with other people. These qualities are critical in social contacts. They foresee the ability to use other people's help. They impact and extend the quality of care provided by relatives for an old person" $(2004, \mathrm{p} .46)$.

Communication proficiency of old people and understanding of their problems among people surrounding them is, therefore, the only opportunity and the only way to fulfil specific needs of elderly people. With age not only the nature and power of needs changes but also the ways they can be fulfilled. B. Synak mentioned some specific needs of seniors: (1) need of belonging - integration and fellowship, (2) need of usefulness, appreciation and participation in organised social activity, (3) need of economical and living space independency, (4) need of psychological and physical safety, (5) need of satisfaction of life (1982, p. 38). Fulfilment of most of these needs requires an opportunity to communicate with other people. All problems presented above physical, psychological and social - escalate the primary barriers and create new ones. Therefore, they impact the physical and psychological condition and well-being of seniors and make future communication even more difficult. As Jon Nussbaum, Loretta Pecchioni and James Robinson, (2000, p. xvii) wrote in their preface, everyone probably knows some people over 65 so the barriers described in this paper apply to quite a big portion of the population. Better communication with the ever growing population of elderly people ${ }^{10}$ is the chance to limit their social isolation and solitude ${ }^{11}$.

10 According to National General Census 2011 people over 65 make 13,6\% of Polish society. See: National General Census 2011. Population. State and social-demographic structure. Warsaw 2013. Retrieved April 03, 2014 from http://www.stat.gov.pl/cps/rde/xbcr/gus/LUD_ludnosc_stan_str_dem_spo_NSP2011.pdf.

11 As P. Czekanowski (2002) defines: loneliness is an objective absence of contacts with other people while solitude is a subjective and upsetting reaction to such absence. 
Journal of Education Culture and Society No. 2_2014

\section{REFERENCES}

Ask Polska, Retrieved May 3, 2016, from http:/ / pl.ask.com.

Bień B. (2002). Stan zdrowia i sprawności osób starszych [Health condition and fitness of old people] (pp. 35-77). In: B. Synak (Ed.) (2002). Polska starość [Polish old age]. Gdańsk: Wydawnictwo Uniwersytetu Gdańskiego.

Bugajska, I. (2005, July 01). Jak dziadkowie buszuja w sieci [How the oldies poke around the Web]. Retrieved from http:/ / wiadomosci.gazeta.pl/Wiadomosci/1,80279,2798598.html.

Co piszczy w prasie dla Seniorów: subiektywny przegląd magazynów dla osób 50+ [What peeps in the grass: subjective review of magazines for people 50+]. Retrieved July 12, 2014, from http:/ / www.czerwonyportfelik. $\mathrm{pl} /$ czytelnia/przeglad-prasy-dla-seniorow.

Czekanowski P. (2002). Rodzina w życiu osób starszych i osoby starsze w rodzinie [Family in old people's life and old people in family] (pp. 140-172). In B. Synak (Ed.) (2002). Polska starość [Polish old age]. Gdańsk: Wydawnictwo Uniwersytetu Gdańskiego.

Definition of an older or elderly person. Retrieved May 10, 2014, from http:/ / www.who.int/healthinfo/survey/ ageingdefnolder/en/.

Głogowska, M. (2005, July 22). Lewa strona gobelinu [Left side of arras]. Gazeta Wyborcza.

Jasna Góra: Sanctuary of the Black Madonna of Częstochowa. Retrieved July 1, 2014, from http:/ / www.jasnagora.pl/en.

Kołakowski, L. (2004). O stereotypach narodowych [About national stereotypes] (pp. 199-204). In: L. Kołakowski. Mini wykłady o maxi sprawach [Mini lectures about big issues]. Kraków: Wydawnictwo Znak.

Ludność. Stan i struktura demograficzno-spoteczna: Narodowy Spis Powszechny Ludności i Mieszkań 2011. Retrieved April 3, 2014, from http://www.stat.gov.pl/cps/rde/xbcr/gus/LUD_ludnosc_stan_str_dem_spo_NSP2011.pdf.

Nussbaum, J.F., \& Coupland, J. (1995). Handbook of Communication and Aging Research. Mahwah, NJ: Lawrence Erlbaum Associates.

Nussbaum, J.F., Pecchioni, L.L., Robinson, J.D., \& Thompson, T.L. (2000). Communication and Aging, Mahwah, NJ: Lawrence Erlbaum Associates.

Piontek, D. (1993). Stereotyp: geneza, cechy, funkcje [Stereotype: genesis, qualities, functions] (pp. 20-40). In: K. Borowczyk, \& P. Pawełczyk. W kręgu mitów i stereotypów [In a circle of myths and stereotypes]. Poznań - Toruń: Wydawnictwo Adam Marszałek

Piotrowski, J. (1973). Miejsce człowieka starego w rodzinie i społeczeństwie [Old person's place in family and society]. Warsaw: Państwowe Wydawnictwo Naukowe.

Sanktuarium Matki Bożej Licheńskiej [Shrine of our Lady of Lichen]. Retrieved July 1, 2014, from http:/ / www. lichen.pl/pl/378/jezyki_obce.

Sobkowiak, B. (1998). Komunikowanie społeczne [Social communication] (pp. 10-21). In B. Dobek-Ostrowska (Ed.). Wspótczesne systemy komunikowania [Contemporary Communication Systems]. Wrocław: Wydawnictwo Uniwersytetu Wrocławskiego

Synak B. (1982). Migracja i adaptacja ludzi starych do środowiska miejskiego [Migration and adaptation of elderly people to urban environment]. Gdańsk: Wydawnictwo Uniwesytetu Gdańskiego.

Synak, B. (Ed.). (2002). Polska starość [Polish old age]. Gdańsk: Wydawnictwo Uniwersytetu Gdańskiego.

Szarota, Z. (2004). Gerontologia spoteczna i oświatowa. Zarys problematyki [Social and educational gerontology. Problem outline]. Kraków: Wydawnictwo Naukowe Akademii Pedagogicznej.

Viorst, J. (1996). To co musimy utracić czyli miłość, złudzenia, zależności i niemożliwe do spetnienia oczekiwania, których każdy z nas musi się wyrzec, by móc wzrastać [Necessary Losses: The Loves, Illusions, Dependencies, and Impossible Expectations that All of Us Have to Give up in Order to Grow]. Poznań: Zysk i S-ka.

World Health Organization. Definition of an older or elderly person. Retrieved July 14, 2014, from http:/ / www. who.int/healthinfo/survey/ageingdefnolder/en/.

Zając, L. (2002). Psychologiczna sytuacja człowieka starszego oraz jej determinanty [Psychological situation of old person and it's determinants] (pp. 53-112). In: K. Obuchowski (Ed.). Starość i osobowossć [Old age and personality]. Bydgoszcz: Akademia Bydgoska im. Kazimierza Wielkiego. 